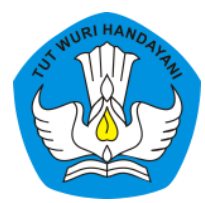

Page: 701-714

\title{
MAKE A MATCH UNTUK MENINGKATKAN HASIL BELAJAR PENDIDIKAN AGAMA KRISTEN
}

\author{
Raditya Wardhani \\ Sekolah Menengah Pertama Negeri 13 Surakarta, Jawa Tengah, Indonesia \\ Contributor Email: ch.radityawardhani@gmail.com
}

\begin{abstract}
This study aims to describe Make A Match based on dart game with paper chain to improve learning outcomes of Christian Religious Education's students at class VIII D in SMPN 13 Surakarta of Even Semester Academic Year 2019/2020. The subjects of this study were students of class VIII D SMPN 13 Surakarta in the 2019/2020, totaling 6 childresn. This research is a Classroom Action Research to improve the quality lerning in the classroom. Data was collected through observation, tests, and documentation. Data analysis was carried out to make conclusions and descriptions of the data based on the conditions as they were. The result showed that make a match based on dart game with paper chain can improve learning outcomes in the first cycle of action. The percentage of results in action cycle I and II wihich values above the KKM before action is 4 children or $66,67 \%$ becomes 3 children or $50 \%$ in action cycle I and 1 children or $16,67 \%$ in action cycle II.
\end{abstract}

Keywords: Make a Matc; Dart; Paper Chain; Outcomes. 


\begin{abstract}
Abstrak
Penelitian ini bertujuan untuk mendeskripsikan make a matc berbasis permainan dart dengan kertas berantai untuk meningkatkan hasil belajar Pendidikan Agama Kristen peserta didik kelas VIII D SMP Negeri 13 Surakarta. Penelitian dilakukan pada semester genap tahun pelajaran 2019/2020. Subyek penelitian ini adalah peserta didik kelas VIII D SMP Negeri 13 Surakarta tahun pelajaran 2019/2020 yang berjumlah 6 anak. Penelitian ini merupakan Penelitian Tindakan Kelas untuk memperbaiki atau meningkatkan kualitas pembelajaran di kelas. Pengumpulan data dilakukan melalui observasi, tes, dan dokumentasi. Analisis data dilakukan untuk membuat kesimpulan dan deskripsi data didasarkan pada kondisi apa adanya. Hasil penelitian menunjukkan bahwa make a matc berbasis permainan dart dengan kertas berantai dapat meningkatkan hasil belajar Pendidikan Agam Kristen kelas VIII D SMP Negeri 13 Surakarta tahun pelajaran 2019/2020. Persentase peningkatan tindakansiklus I dan II yaitu nilai di bawah KKM sebelum tindakan sebanyak 4 anak atau 66,67\% menjadi 3 anak atau 50\% pada siklus I dan 1 anak atau 16,67\% pada siklus II.
\end{abstract}

Kata Kunci: Make a Match; Dart; Kertas berantai; Hasil belajar.

\title{
A. Pendahuluan
}

Sekolah sebagai tempat belajar dan mengajar diharapkan dapat menghasilkan perubahan yang bermanfaat bagi peserta didik, pendidik dan lingkungan. Sekolah berfungsi untuk memberikan pengetahuan umum, keterampilan dasar, membentuk peserta didik menjadi makhluk sosial yang bertanggung jawab, alat transformasi kebudayaan dan mempersiapkan peserta didik terjun dalam dunia kerja. Fungsi sekolah untuk memberikan pengajaran sehingga mmenjadi pribadi yang berguna bukan hanya bagi dirinya sendiri tapi juga bagi lingkungan sekitarnya. Besar harapan orang tua terhadap sekolah serta pentingnya fungsi sekolah, diharapkan sekolah mampu menjalankan peran dan fungsinya dalam tugas pembelajaran.

Sekolah tidak dapat menjalankan peran serta fungsi tersebut tanpa dukungan dari setiap unsur yaitu bangunan sekolah, peserta didik, pendidik dan tenaga kependidikan, sarana dan prasarana, wali peserta didik dan masyarakat. Orang tua memiliki peran yang penting sebagai motivator bagi peserta didik dalam menempuh pendidikan di sekolah. Peran orang tua sebagai pendidik untuk sementara waktu digantikan dan diserahkan sepenuhnya kepada guru. Guru sebagai pihak yang terlibat langsung dalam proses 
pembelajaran di kelas memiliki peran yang sangat vital dalam meningkatkan kualitas anak didiknya. Keberhasilan proses pendidikan dapat dikatakan sangat tergantung pada peran guru di sekolah (Muhson, 2004).

Harianto menjelaskan bahwa Pendidikan Agama Kristen adalah usaha sadar dan terencana untuk meletakkan dasar Yesus Kristus (2 Kor. 3:13) dalam pertumbuhan iman Kristus dengan cara mewujudkan suasana belajar dan proses pembelajaran agar peserta didik secara aktif mengembangkan potensinya untuk memiliki kekuatan spiritual keagamaan, yaitu melandaskan pengendalian diri, kepribadian, kecerdasan, akhlak mulia, serta keterampilan yang diperlukan dirinya dan masyarakat (Harianto, 2012). Agar pelajaran Pendidikan Agama Kristen (PAK) dapat berjalan efektif seperti yang diharapkan maka harus dilaksanakan dengan sadar dan terencana menggunakan strategi, model dan media pembelajaran yang tepat. Tugas utama guru PAK adalah mendidik, mengajar, membimbing dan melatih peserta didik untuk dapat bertumbuh secara rohani. Guru agama kristen, harus memiliki kualitas seperti tanggung jawab dan disiplin karena guru agama Kristen harus dapat mengambangkan sikap, watak, nilai moral, dan potensi peserta didik untuk menjadi dewasa secara rohani serta beriman dan taat kepada Tuhan Yesus (Groome, 2015). Guru PAK harus memiliki kemampuan memilih, menggunakan dan mengolah metode, media, strategi yang tepat dalam proses belajar mengajar supaya dapat menarik minat dan mempertahankan motivasi belajar peserta didik sehingga dapat meningkatkan hasil belajar PAK.

Faktanya, hasil belajar PAK peserta didik kelas VIII D masih rendah. Dari hasil observasi kondisi awal ditemukan penyebab rendahnya hasil belajar diantaranya (1) kecenderungan peserta didik untuk berbicara sendiri dengan teman pada saat guru menjelaskan materi pelajaran; (2) peserta didik kurang aktif mengikuti kegiatan diskusi kelompok; (3) rendahnya minta belajar PAK karena dianggap sebagai mata pelajaran yang kurang penting dibandingkan mata pelajaran yang diujikan dan (4) guru PAK terlalu cepat dalam menjelaskan materi. Rendahnya hasil belajar PAK pada kondisi awal didapati bahwa Kriteria Ketuntasan Minimal (KKM) yang ditetapkan di sekolah untuk mata pelajaran PAK adalah 70, sedangkan peserta didik kelas VIII D yang memperoleh nilai minimal atau melampaui KKM hanya 2 anak 
yaitu hanya 33,3\% dari keseluruhan peserta didik yang berjumlah 6 orang. Masih ada 4 peserta didik yang belum tuntas KKM atau 66,7\% peserta didik yang memperoleh nilai PAK dibawah KKM.

Menghadapi kondisi tersebut, penulis mencoba mengubah strategi mengajar menggunakan metode baru berbasis permainan. Pemilihan metode belajar berbasis permainan karena dengan permainan yang menarik diharapkan dapat meningkatkan minat peserta didik terhadap materi yang akan dipelajari dan nantinya berdampak pada peningkatan hasil belajar. Sejalan dengan hal tersebut, Frobel dalam Tedjasaputra lebih menekankan pentingnya bermain dalam belajar karena berdasarkan pengalamannya sebagai guru, dia menyadari bahwa kegiatan bermain maupun mainan yang dinikmati anak dapat digunakan untuk menarik perhatian serta mengambangkan pengetahuan mereka (Tedjasaputra, 2001). Make a match berbasis permainan dart dengan kertas berantai ini merupakan metode yang mengajak peserta didik bermain dalam kelompok untuk mencari dan mencocokkan soal dan jawaban di kartu yang sudah disediakan, mendiskusikannya secara aktif dalam kegiatan diskusi kelompok, setelah diperoleh kecocokan antara kartu soal dan jawaban, kedua kartu tersebut kemudian diletakkan di kertas berantai untuk kemudian dipresentasikan di depan kelas.

Dasar dari dilaksanakannya metode make a match ini adalah pembelajaran kooperatif. Eggen dan kauchak dalam Trianto menjelaskan bahwa Cooperative learning atau pembelajaran kooperatif merupakan sebuah sebuah kelompok strategi pengajaran yang melibatkan siswa bekerja secara berkolaborasi untuk mencapai tujuan bersama (Trianto, 2007). Cooperative learning adalah strategi pembelajaran yang cukup berhasil pada kelompok-kelompok kecil, di mana pada tiap kelompok tersebut terdiri dari siswa-siswa dari berbagai tingkat kemampuan, melakukan berbagai kegiatan belajar untuk meningkatkan pemahaman mereka tentang materi pelajaran yang sedang dipelajari. Setiap anggota kelompok bertanggung jawab untuk tidak hanya belajar apa yang diajarkan tetapi juga untuk membantu rekan rekan belajar, sehingga bersamasama mencapai keberhasilan. Semua Siswa berusaha sampai semua anggota kelompok berhasil memahami dan melengkapinya. 
Penulis meyakini bahwa dengan make a match berbasis permainan dart dengan kertas berantai dapat menjadi solusi alternatif meningkatkan minat belajar yang akhirnya dapat meningkatkan hasil belajar PAK peserta didik kelas VIII D SMP Negeri 13 Surakarta. Tujuan penelitian ini adalah untuk meningkatkan hasil belajar PAK. Manfaat penelitian ini untuk memberikan wawasan baru tentang metode pembelajaran yang kreatif dan inovatif untuk meningkatkan hasil belajar peserta didik.

\section{B. Metode}

Penelitian ini menggunakan Penelitian Tindakan Kelas yang dilakukan melalui dua siklus. Anjani mengatakan Penelitian Tindakan Kelas adalah penelitian praktis yang dimaksudkan untuk memperbaiki pembelajaran di kelas. Penelitian ini merupakan salah satu upaya guru atau praktisi dalam bentuk berbagai kegiatan yang dilakukan untuk memperbaiki dan atau meningkatkan mutu pembelajaran di kelas (Pandiangan, 2019). Melalui penelitian ini diharapkan guru dapat memperbaiki layanan pendidikan di kelas.

Penelitian ini dilakukan di SMP Negeri 13 Surakarta dengan subyek penelitian berjumlah 6 peserta didik pada kelas VIII D. Teknik pengumpulan data menggunakan observasi dan wawancara untuk mengamati sampai sejauh mana tindakan yang dilakukan memberi pengaruh terhadap tujuan yang hendak dicapai dan mengumpulkan data pada awal dan akhir kegiatan. Validitas data digunakan triangulasi untuk menjamin dan mengembangkan validitas data.Triangulasi yang digunakan diperoleh dari dokumen, observasi dan tes. Data yang berupa hasil pengamatan dianalisis secara deskriptif dengan membandingkan hasil implementasi make a match berbasis permainan dart dengan kartas berantai antar tahap. Analisis dilakukan untuk mengetahui tingkat efektivitas sebelum dan sesudah dilaksanakannya dalam kegiatan pembelajaran PAK. Indikator keberhasilan dalam penelitian ini sekurang-kurangnya $80 \%$ peserta didik memperoleh nilai minimal KKM mata pelajaran PAK yaitu 70.

Tindakan yang dilakukan dalam penelitian ini meliputi empat tahap yaitu perencanaan, pelaksanaan, pengamatan dan refleksi. Tahap pertama 
adalah perencanaan.Tahap perencanaan diwujudkan dengan penyusunan skenario pembelajaran menggunakan model pembelajaran make a match berbasis permainan dart dengan kertas berantai. Tahap kedua pelaksanaan tindakan yaitu keseluruhan tindakan yang dilaksanakan dalam penulisan ini bertujuan untuk mengadakan perbaikan terhadap kegiatan penggunaan model pembelajaran make a match berbasis permainan dart dengan kertas berantai. Tahap ketiga adalah pengamatan dan observasi. Pengamatan dan observasi merupakan kegiatan pemantauan yang dilakukan untuk memonitor tindakan yang terjadi di kelas. Penulis mengamati jalannya proses pembelajaran yang terjadi di dalam kelas sambil mencatat segala sesuatu yang terjadi selama proses pembelajaran berlangsung. Setelah itu diadakan wawancara dengan kolaboran mengenai hasil pengamatan. Dalam forum wawancara tersebut, diungkapkan kelemahan dan kelebihan model pembelajaran make a match berbasis permainan dart dengan kertas berantai. Tahap keempat adalah refleksi. Pada tahap ini penulis menganalisi atau mengolah data yang telah dikumpulkan, kemudian menyajikan dalam pertemuan dengan guru yang bersangkutan. Setelah dilakukan diskusi dan bertukar pikiran dengan guru, diambil suatu kesimpulan yang berupa hasil dari pelaksanaan penelitian. Dari hasil penarikan kesimpulan ini, dapat diketahui apakah penelitian ini berhasil atau tidak, sehingga dapat ditentukan langkah selanjutnya.

Langkah-langkah kegiatan pembelajaran menggunakan make a match berbasis permainan dart dengan kertas berantai meliputi persiapan, pelaksanaan dan evaluasi. Persiapan meliputi menyiapkan kartu soal, kertas berantai, kotak tempat kartu, dart, dan papan dart. Kartu soal dibuat 10 dan kartu jawaban dibuat 10 sesuai jumlah kartu soal. Kertas berantai dibuat dari kertas cover dibuat dalam warna yang berbeda sesuai dengan jumlah kelompok yang akan dibentuk dan diberi tulisan ' $\mathrm{P}$ ' untuk tempat menempelkan kartu pertanyaan dan 'J' untuk menempelkan kartu jawaban. Kotak tempat kartu dibuat dua kotak untuk masing-masing kelompok. Satu kotak diberi tulisan ' $\mathrm{P}$ ' untuk meletakkan kartu pertanyaan dan kotak lain diberi tulisan 
'J' untuk meletakkan kartu jawaban. Dart atau anak panah dibeli di toko mainan atau dibuat dari paku, masing-masing kelompok diberikan satu dart untuk dilemparkan di papan dart. Papan dart dibuat dari kertas kardus atau stereofom dengan dibuat kotak-kotak atau lingkaran-lingkaran yang diberi huruf ' $\mathrm{P}$ ' dan ' $\mathrm{J}$ '.

Pelaksanaan dilakukan dengan membagikan tiap kelompok dibagikan 1 dart untuk dilemparkan ke papan dart. Tiap kelompok akan melemparkan dart ke papan dart, bila mengenai huruf 'J' maka kelompok tersebut akan mengambil satu kartu jawaban dari kotak yang berisi kartu jawaban. Bila dart mengenai papan dart dengan tulisan ' $\mathrm{P}^{\prime}$, kelompok tersebut akan mengambil satu kartu pertanyaan dari kotak yang berisi pertanyaan. Masingmasing kelompok mendiskusikan kartu yang diperoleh dan mencari pasangannya kemudian menempelkan kartu tersebut di kertas berantai demikian seterusnya sampai semua kartu habis, atau sampai batas waktu yang diberikan habis. Setelah tiap kelompok sudah menyelesaikan kertas berantai, diberi kesempatakan untuk mempresentasikannya di depan kelas. Di akhir kegiatan akan dilaksanakan evaluasi dengan menggunakan tes buatan guru untuk mengetahui sejauh mana ketercapaian pembelajaran dengan menggunakan make a match berbasis permainan dart dengan kertas berantai.

\section{Hasil dan Pembahasan}

Pada penelitian ini, indikator ketercapaiannya sekurang-kurangnya $80 \%$ peserta didik kelas VIII D memperoleh nilai hasil belajar minimal KKM yaitu 70.

\section{Hasil}

Hasil belajar dari tindakan kelas ini adalah meningkatnya hasil belajar PAK materi bersyukur dengan menggunakan make a match berbasis permainan dart dengan kertas berantai.

Pelaksanaan siklus I pada penelitian ini dimulai dengan merencanakan kegiatan. Pada tahap ini peneliti menyiapkan perangkat pembelajaran seperti 
RPP, LKPD, dart (anak panah), papan dart, kartu pertanyaan dan kartu jawaban dengan warna yang berbeda disesuaikan dengan jumlah kelompok yang akan dibuat, kotak tempat kartu jawaban dan kartu pertanyaan, dan kertas berantai yang dibuat dengan warna yang berbeda menyesuaikan dengan jumlah kelompok yang akan dibuat. Karena dalam penelitian ini dibagi dalam 3 kelompok, peneliti membuat kartu pertanyaan, kartu jawaban, dan kertas berantai dengan 3 warna yang berbeda. Pada siklus I ini direncanakan pertanyaan di kartu pertanyaan dan jawaban di kartu jawaban disiapkan secara mandiri oleh peserta didik dalam kelompok.

Pelaksanaan dilakukan pada jam pelajaran PAK. Tahap ini diawali dengan pengenalan permainan dart oleh guru kepada peserta didik. Guru menjelaskan prosedur operasional make a match berbasis permainan dart dengan kertas berantai. Setelah peserta didik mengerti alur proses pembelajaran, kelas dibagi menjadi tiga kelompok heterogen dengan jumlah anggota dua orang per kelompok. Tiap kelompok diberi waktu untuk membaca buku paket Pendidikan Agama Kristen dan Budi Pekerti Kelas 8 bab XI dengan tema "Mengapa Bersyukur?" kemudian berdiskusi dengan teman kelompok membuat 10 pertanyaan dan 10 jawaban dari pertanyaan yang sudah dibuat. Pertanyaan dan jawaban tersebut kemudian dituliskan di kartu-kartu yang sudah disiapkan guru sebelumnya.

Setelah masing-masing kelompok siap dengan kartu yang berisi pertanyaan dan kartu yang berisi jawaban, kartu-kartu tersebut ditukar dengan kelompok lain dan kegiatan belajar mengajar menggunakan make a match berbasis permainan dart dengan kertas berantai siap dimulai.

Pada akhir pembelajaran, peserta didik diberi tes tertulis untuk mengetahui tingkat keberhasilan proses pembelajaran dengan menggunakan make a match berbasis permainan dart dengan kertas berantai ini. Dari data ratarata hasil belajar siklus I terlihat ada peningkatan.

Rekap rata-rata hasil belajar peserta didik pada pelajaran PAK materi bersyukur menggunakan make a match berbasis permainan dart dengan kertas berantai siklus I tampak pada tabel berikut. 
Tabel 1.Rata-rata Hasil Belajar Siklus I

\begin{tabular}{|c|c|c|c|}
\hline $\begin{array}{l}\text { N } \\
\text { o. }\end{array}$ & Uraian & Hasil & Keterangan \\
\hline 1. & $\begin{array}{l}\text { Nilai rata-rata hasil } \\
\text { belajar }\end{array}$ & 71,67 & $\begin{array}{l}\text { Nilai rata-rata hasil belajar sebelum tindakan dan } \\
\text { setelah dilaksanakannya siklus I menunjukkan pening- } \\
\text { katan dari } 66,67 \text { menjadi } 71,67\end{array}$ \\
\hline 2. & $\begin{array}{l}\text { Jumlah peserta didik yang } \\
\text { memperoleh nilai minimal } \\
\text { dan atau diatas KKM }\end{array}$ & 3 & $\begin{array}{l}\text { Jumlah peserta didik yang tuntas sebelum tindakan } \\
\text { dan setelah dilaksanakan siklus I menunjukkan pening- } \\
\text { katan dari } 2 \text { peserta didik menjadi } 3 \text { peserta didik }\end{array}$ \\
\hline 3. & $\begin{array}{l}\text { Persentase ketuntasan } \\
\text { belajar }\end{array}$ & $50 \%$ & $\begin{array}{l}\text { Persentase ketuntasan belajar sebelum tinda-kan } \\
\text { dan setelah dilaksanakan siklus I mening-kat 33,33\% } \\
\text { menjadi } 50 \%\end{array}$ \\
\hline
\end{tabular}

Observasi pelaksanaan siklus I sudah ada peningkatan hasil belajar. Meskipun sudah menunjukkan adanya peningkatan, belum memenuhi kriteria ketuntasan yaitu 80\% peserta didik memperoleh nilai minimal KKM yaitu 70. Penelitian ini direncanakan dilakukan dalam 2 siklus sehingga dilanjutkan ke siklus II.

Pada siklus I ini ditemukan beberapa persoalan yang membutuhkan perbaikan diantaranya kartu pertanyaan dan kartu jawaban yang berisi pertanyaan dan jawaban yang dibuat oleh masing-masing kelompok untuk didiskusikan dan dikerjakan oleh kelompok lain ternyata tidak berjalan seperti yang diharapkan. Tiap kelompok mengalami kesulitan untuk mencari pasangan dari masing-masing kartu. Hal ini diduga karena pertanyaan dan jawaban yang dibuat oleh tiap kelompok bahasanya masih berantakan, kalimatnya tidak sistematis serta terlalu panjang sehingga susah dipahami. Untuk itu, di siklus II akan dilakukan metode yang berbeda. Kartu peryanyaan dan kartu jawaban akan disiapkan oleh guru mata pelajaran. Beberapa peserta didik belum bisa melemparkan dart dengan baik sehingga sering meleset dan tidak mengenai sasaran. Kegagalan melempar dart menyebabkan pendistribusian waktu tidak berjalan dengan lancar.Tiap kelompok perlu belajar melempar dart dengan baik supaya tidak terulang kesalahan yang sama.

Pada pelaksanaan siklus II, diawali perencanaan yang dilakukan guru dengan menyiapkan perangkat pembelajaran, RPP, LKPD, dart (anak panah), papan dart, kartu pertanyaan dan kartu jawaban, kotak tempat kartu jawaban dan kartu pertanyaan, dan kertas berantai yang pada siklus II ini pertanyaan di kartu pertanyaan dan jawaban di kartu jawaban disiapkan oleh guru. 
Pelaksanaan siklus II dilakukan pada jam pelajaran PAK. Berbeda dengan siklus I yang diawali dengan pengenalan permainan dart, di siklus II ini peserta didik langsung masuk ke dalam kelompok masing-masing seperti yang sudah dibentuk pada siklus I. Masing-masing kelompok diberi kesempatan untuk membaca kembali buku paket Pendidikan Agama Kristen dan Budi Pekerti Kelas VIII Bab 12 dengan tema Bersyukur Bukan Sekedar Pasrah. Prosedur operasional make a match berbasis permainan dart dengan kertas berantai masih sama dengan siklus I, yang berbeda hanyalah kartu pertanyaan dan kartu jawaban telah disediakan terlebih dahulu oleh guru.

Wakil tiap kelompok bergantian melemparkan dart ke papan dart kemudian mengambil kartu seperti hasil dari lemparan dart. Setelah mengambil kartu, wakil kelompok kembali untuk mendiskusikan kartu yang diperoleh dengan anggota kelompok yang lain. Setelah sepakat dengan hasil jawaban, wakil kelompok mengambil kartu yang cocok di kotak yang sudah disiapkan kemudian diletakkan di kertas berantai dengan posisi berdampingan. Setelah keseluruhan kartu pertanyaan dan jawaban mendapatkan pasangan, tiap kelompok mempresentasikan hasil kerja kelompok di depan kelas. Guru memberi apresiasi kepada kelompok yang terlebih dahulu berhasil menyelesaikan kertas berantai dengan benar.

Pada akhir pembelajaran, peserta didik diberi tes tertulis untuk mengetahui tingkat keberhasilan proses pembelajaran dengan menggunakan make a match berbasis permainan dart dengan kertas berantai ini. Dari data rata-rata hasil belajar siklus II terlihat ada peningkatan.

Rekap rata-rata hasil belajar peserta didik pada pelajaran PAK materi bersyukur menggunakan make a match berbasis permainan dart dengan kertas berantai siklus II tampak pada tabel berikut.

\section{Tabel 2. Rata-rata Hasil Belajar Siklus II}

\begin{tabular}{clcl}
\hline No & \multicolumn{1}{c}{ Uraian } & Hasil & \multicolumn{1}{c}{ Keterangan } \\
\hline 1 & Nilai rata-rata hasil belajar & 80,83 & $\begin{array}{l}\text { Nilai rata-rata hasil belajar siklus I dan } \\
\text { siklus II menunjukkan peningkatan dari 71,67 } \\
\text { menjadi 80,83 }\end{array}$ \\
2 & $\begin{array}{l}\text { Jumlah peserta didik yang } \\
\text { memperoleh nilai minimal dan } \\
\text { atau diatas KKM }\end{array}$ & 5 & $\begin{array}{l}\text { Jumlah peserta didik yang tuntas pada siklus I } \\
\text { dan siklus II menunjukkan peningkatan } \\
\text { dari 3 peserta didik menjadi 5 peserta didik }\end{array}$ \\
Persentase ketuntasan belajar & 83,33\% & $\begin{array}{l}\text { Persentase ketuntasan belajar siklus I dan } \\
\text { siklus II meningkat dari 50\% menjadi 83,33\% }\end{array}$ \\
\hline
\end{tabular}




\section{Raditya Wardhani}

Berdasar hasil observasi pelaksanaan siklus II sudah menunjukkan adanya peningkatan yang memenuhi kriteria ketuntasan yaitu $80 \%$ peserta didik memperoleh nilai minimal KKM yaitu 70. Penelitian ini direncanakan dilakukan dalam 2 siklus, dengan hasil tindakan siklus II ini maka penelitian tidak dilanjutkan ke siklus berikutnya. Make a match berbasis permainan dart dengan kertas berantai dianggap berhasil meningkatkan hasil belajar PAK materi bersyukur pada peserta didik kelas VIII D SMP Negeri 13 Surakarta semester genap tahun pelajaran 2019/2020.

Beberapa persoalan yang muncul pada siklus I sudah berhasil diatasi di siklus II. Kartu pertanyaan dan kartu jawaban yang berisi perntanyaan dan jawaban yang dibuat dan disiapkan guru dapat didiskusikan dan dikerjakan oleh tiap kelompok untuk kemudian dipresentasikan di depan kelas. Kesulitan melempar dart dapat diatasi dengan belajar melempar dart di rumah. Pendistribusian waktu sudah berjalan dengan baik sehingga pembelajaran berjalan dengan baik. Beberapa kendala tetap ada namun tidak menimbulkan masalah yang berarti dan bisa segera diatasi.

\section{Pembahasan}

Sebelum dilaksanakannya tindakan kelas menggunakan make a match berbasis permainan dart dengan kertas berantai, ditemukan kecenderungan peserta didik untuk berbicara sendiri dengan teman kiri kananya pada saat guru menjelaskan materi pelajaran, peserta didik kurang aktif mengikuti kegiatan diskusi kelompok, rendahnya minta belajar PAK karena dianggap sebagai mata pelajaran yang kurang penting dibandingkan mata pelajaran yang diujikan dan guru PAK yang terlalu cepat dalam menjelaskan materi. Rendahnya hasil belajar PAK pada kondisi awal menjadi bukti ketidakefektifan pembelajaran PAK yang dilakukan oleh guru.

Melalui perubahan metode pembelajaran diharapkan dapat meningkatkan minat belajar peserta didik yang akhirnya berdampak pada peningkatan hasil belajar. Fathurrohman dan Sutikno (2010) menjelaskan bahwa metode mengajar adalah cara-cara menyajikan bahan pelajaran kepada siswa untuk tercapainya tujuan yang ditetapkan. Keterampilan guru memilih metode yang tepat memegang peranan penting dalam pengajaran, karena 
pemilihan metode berkaitan langsung dengan usaha-usaha guru dalam menampilkan pengajaran yang sesuai dengan situasi dan kondisi sehingga pencapaian tujuan pengajaran diperoleh secara optimal (Sutikno, 2010). Hal ini mendasari peneliti untuk menggunakan metode make a match berbasis permainan dart dengan kertas berantai dengan harapan metode yang digunakan dapat membangkitkan minat belajar peserta didik dan menghilangkan asumsi negatif bahwa pelajaran PAK tidak penting sehingga berdampak pada peningkatan hasil belajar.

Setelah dilakukan perbaikan menggunakan make a match berbasis permainan dart dengan kertas berantai, ternyata ada perubahan yang cukup signifikan. Peserta didik terlihat cukup antusian mengikuti pelajaran PAK dan terlibat lebih aktif dalam kegiatan diskusi. Antusianme dan keaktifan belajar peserta didik berdampak pada peningkatan hasil belajar PAK materi bersyukur.

Dari hasil evaluasi siklus I dan siklus II menggunakan make a match berbasis permainan dart dengan kertas berantai mengalami peningkatan. Jumlah peserta didik yang memperoleh nilai minimal KKM pada siklus I sebanyak 3 orang dan siklus II menjadi 5 orang. Rata-rata hasil belajar siklus I dan siklus II materi bersyukur mengalami peningkatan dari 66,67pada siklus I menjadi 80,83 pada siklus II. Persentase ketuntasan belajar siklus I dan siklus II mengalami peningkatan dari 50\% pada siklus I menjadi $83,33 \%$ pada siklus II. Hal ini sesuai dengan kriteria ketuntasan yaitu 80\% peserta didik atau 5 orang memperoleh nilai minimal KKM yaitu 70.

Peningkatan hasil belajar peserta didik siklus I ke siklus II menggunakan make a match berbasis permainan dart dalam pembelajaran PAK materi bersyukur kelas VIII D SMP Negeri 13 Surakarta dapat dilihat dalam tabel berikut:

Tabel 3. Peningkatan Hasil Belajar Siklus I dan Siklus II

\begin{tabular}{lccc}
\hline $\begin{array}{c}\text { Tindakan yang } \\
\text { dilakukan }\end{array}$ & $\begin{array}{c}\text { Prosentase (\%)Nilai } \\
\text { dibawah KKM }\end{array}$ & $\begin{array}{c}\text { Prosentase (\%)Nilai } \\
\text { diatas KKM }\end{array}$ & Rata-rata \\
\hline Sebelum siklus & $66,67 \%$ & $33,33 \%$ & 66,67 \\
Siklus I & $50,00 \%$ & $50,00 \%$ & 71,67 \\
Siklus II & $16,67 \%$ & $83,33 \%$ & 80,83 \\
\hline
\end{tabular}

Berdasarkan uraian hasil observasi dan rekap hasil belajar siklus I dan siklus II tersebut maka penulis dan observer menyimpulkan bahwa make a match berbasis permainan dart dengan kertas berantai dapat digunakan 
untuk meningkatkan hasil belajar PAK materi bersyukur peserta didik kelas VIII D SMP Negeri 13 Surakarta semester genap tahun Pelajaran 2019/2020.

\section{Penutup}

Berdasarkan hasil penulisan dapatdisimpulkan bahwa make a match berbasis permainan dart dengan kertas berantai dapat meningkatkan hasil belajar PAK materi bersyukur peserta didik kelas VIII D SMP Negeri 13 Surakarta semester genap tahun Pelajaran 2019/2020.

Peningkatan ini ditandai dengan rata-rata hasil belajar peserta didik pada siklus I adalah 66,67 meningkat menjadi 80,83 pada siklus II. Peningkatan ketuntasan peserta didik dari 3 orang pada siklus I menjadi 5 orang pada siklus II. Dan persentase ketuntasan belajar naik dari 50\% pada siklus I menjadi 83,33\% pada siklus II. Aktifitas peserta didik juga mengalami peningkatan. Peserta didik tampak lebih antusias dalam mengikuti pembelajaran PAK dan aktif mengikuti kegiatan diskusi kelompok dan tidak canggung pada saat mempresentasikan hasil diskusi kelompoknya di depan kelas.

Supaya kegiatan pembelajaran PAK semakin aktif, guru diharapkan selalu berinovasi menemukan dan menggunakan media, strategi dan metode belajar yang variatif supaya kegiatan belajar mengajar tidak monoton menggunakan metode konvensional saja sperti ceramah. Kegiatan belajar mengajar direncanakan dan didesaian sekreatif mungkin untuk membangkitkan minat dan motivasi belajar peserta didik. tujuan pembelajaran tidak hanya fokus pada tujuan akhir tapi juga pada proses pembelajaran bermakna.

\section{Ucapan Terimakasih}

Penulis mengucapkan terimakasih kepada ibu Kucisti Ike Retnaningtyas Suryo Putro, selaku Kepala SMP Negeri 13 Surakarta yang sudah memberikan izin dan dorongan terlaksananya penelitian ini. Penulis juga berterimakasih kepada rekan-rekan guru dan karyawan SMP Negeri 13 Surakarta atas dukungan yang diberikan sehingga penelitian ini bisa terselesaikan. Terimakasih kepada ibu Anik Suryaningsih, S.Pd. sebagai kolaborator penelitian. Terimakasih juga kepada peserta didik kelas VIII D SMP Negeri 13 Surakarta semester genap tahun pelajaran 2019/2020 atas kersajamanya dalam kegiatan pembelajaran. 


\section{Daftar Referensi}

Ali, M. (2004). Meningkatkan Profesionalisme Guru: Sebuah Harapan. Jurnal Ekonomi E Pendidikan, 2(1), 90-98.

Anjani Putri Belawati Pandiangan. (2019). Penelitian Tindakan Kelas. Jogjakarta: Deepublish.

Dewi, N., \& Atun, S. (2019). The Effect of Science Technology Society (STS) Learning On Students' Science Process Skills. Jurnal Ilmiah Peuradeun, 7(1), 113-124. doi:10.26811/peuradeun.v7i1.288

Harianto, G. (2012). Pendidikan Agama Kristen dalam Alkitab dan Dunia Pendidikan Masa Kini. Andi.

Hastaty Lanusi, D. . (2018). Penerapan Kelas Digital Edmodo untuk Meningkatkan Minat Belajar dan Hasil Belajar Siswa. Jurnal Didaktika Pendidikan Dasar, 2(1), 67-82.

Istafada, I. (2021). Media Potbangtar Meningkatkan Hasil Belajar Menghitung Luas Bangun Datar pada Siswa Sekolah Dasar. Jurnal Didaktika Pendidikan Dasar, 5(1), 71-90. https://doi.org/10.26811/didaktika.v5i1.283

Mayke S. Tedjasaputra. (2001). Bermain, Mainan dan Permainan untuk Pendidikan Usia Dini. Bandung: Grasindo.

Susanto, J. (2019). Penggunaan Mekubar (Pop Up) untuk Meningkatkan Aktivitas dan Hasil Belajar Siswa Sekolah Dasar. Jurnal Didaktika Pendidikan Dasar, 3(2), 535-550.

Sutikno, P. F. dan M. S. (2010). Strategi Belajar dan Mengajar. Bandung: Refika Aditama.

Tabrani ZA. (2011). Dynamics of Political System of Education Indonesia. International Journal of Democracy, 17(2), 99-113.

Tabrani ZA. (2014). Dasar-Dasar Metodologi Penelitian Kualitatif. Yogyakarta: Darussalam Publishing.

Thomas H. Groome. (2015). Christian Religious Education. Jakarta: BPK Gunung Mulia.

Trianto. (2007). Model-model Pembelajaran Inovatif. Jakarta: Prestasi Pustaka.

Walidin, W., Idris, S., \& Tabrani ZA. (2015). Metodologi Penelitian Kualitatif $\mathcal{E}$ Grounded Theory. Banda Aceh: FTK Ar-Raniry Press. 